\title{
The Influence of Initial Xylose Concentration, Agitation, and Aeration on Ethanol Production by Pichia stipitis from Rice Straw Hemicellulosic Hydrolysate
}

\author{
João Paulo A. Silva • Solange Inês Mussatto • \\ Inês C. Roberto
}

Received: 16 September 2009 / Accepted: 9 November 2009 /

Published online: 28 November 2009

(C) Springer Science+Business Media, LLC 2009

\begin{abstract}
Rice straw hemicellulosic hydrolysate was used as fermentation medium for ethanol production by Pichia stipitis NRRL Y-7124. Shaking bath experiments were initially performed aiming to establish the best initial xylose concentration to be used in this bioconversion process. In the sequence, assays were carried out under different agitation $(100$ to $200 \mathrm{rpm})$ and aeration $\left(\underline{V}_{\text {flask }} / V_{\text {medium }}\right.$ ratio varying from 2.5 to 5.0$)$ conditions, and the influence of these variables on the fermentative parameters values (ethanol yield factor, $Y_{\mathrm{P} / \mathrm{S}}$; cell yield factor, $Y_{\mathrm{X} / \mathrm{S}}$; and ethanol volumetric productivity, $\left.Q_{\mathrm{P}}\right)$ was investigated through a $2^{2}$ full-factorial design. Initial xylose concentration of about $50 \mathrm{~g} / \mathrm{l}$ was the most suitable for the development of this process, since the yeast was able to convert substrate in product with high efficiency. The factorial design assays showed a strong influence of both process variables in all the evaluated responses. The agitation and aeration increase caused a deviation in the yeast metabolism from ethanol to biomass production. The best results $\left(Y_{\mathrm{P} / \mathrm{S}}=0.37 \mathrm{~g} / \mathrm{g}\right.$ and $Q_{\mathrm{P}}=0.39 \mathrm{~g} / \mathrm{l}$.h $)$ were found when the lowest aeration $\left(2.5 V_{\text {flask }} / V_{\text {medium }}\right.$ ratio) and highest agitation $(200 \mathrm{rpm})$ levels were employed. Under this condition, a process efficiency of $72.5 \%$ was achieved. These results demonstrated that the establishment of adequate conditions of aeration is of great relevance to improve the ethanol production from xylose by Pichia stipitis, using rice straw hemicellulosic hydrolysate as fermentation medium.
\end{abstract}

Keywords Ethanol $\cdot$ Fermentation $\cdot$ Hemicellulosic hydrolysate $\cdot$ Pichia stipitis $\cdot$ Rice straw

J. P. A. Silva • I. C. Roberto

Department of Biotechnology, Engineering College of Lorena, University of São Paulo, Estrada Municipal do Campinho s/n, 12602-810 Lorena, SP, Brazil

S. I. Mussatto $(\bowtie)$

IBB - Institute for Biotechnology and Bioengineering, Centre of Biological Engineering,

University of Minho, Campus de Gualtar, 4710-057 Braga, Portugal

e-mail: solange@deb.uminho.pt

e-mail: solangemussatto@hotmail.com 


\section{Introduction}

Bioethanol production has gained large importance in the last few years due to the increased concern for depleting oil reserves, rising crude oil prices, and greenhouse effect $[1,2]$. Besides to be a renewable energy source, ethanol has other important advantages when compared with gasoline since it is an oxygenated fuel (contains $35 \%$ oxygen), and therefore, the emission of NOx and particulate materials from its combustion is lower [3]. Currently, sugarcane, cornstarch, and sugar beet are the main raw materials used for ethanol production by fermentation [4]. Nevertheless, all these products have great use as food, and thus, it is of interest to find new alternative raw materials for this biocombustible production.

Ethanol production from lignocellulose is very attractive because of its low cost and abundance, and non-competition with foodstuffs [5]. Lignocellulosic forestry and agricultural wastes, such as corn stover, rice straw, sugarcane bagasse, wheat straw, rice hull, corncobs, oat hull, corn fiber, woodchip, and cotton stalk have been considered attractive raw materials for ethanol production [2]. Hemicellulose, which is one of the three major components of lignocellulosic biomass together with cellulose and lignin, can be easily hydrolyzed to monomeric sugars under mild conditions [6]. Xylose is the main sugar obtained by hydrolysis of this fraction, and its bioconversion is an important step in the use of lignocellulosic materials. In this sense, the ability of microorganisms to produce ethanol from xylose has been investigated by many researchers [7-9] since Saccharomyces cerevisiae, the most commonly used ethanol producer microorganism, cannot ferment pentoses [2]. In a recent review, Pichia stipitis has been described as the most promising naturally occurring $\mathrm{C}_{5}$ fermenting microorganism [10]; in addition, this yeast is also able of transforming both pentoses and hexoses into ethanol [11] that is an important advantage since both kinds of sugars are currently found in lignocellulosic hydrolysates.

The environmental parameters and composition of the culture medium are important factors affecting the bioconversion process productivity [12]. According to du-Preez [13], aeration is the most important environmental factor in xylose fermentation by yeasts, since it determines the partitioning of the carbon flow substrate between growth and product formation. In fact, Taniguchi et al. [14] reported that P. stipitis CBS 5773 consumed an insignificant amount of xylose and did not produce ethanol from xylose under anaerobic conditions. Nigam [15] also verified slow xylose consumption by $P$. stipitis NRRL Y-7124 under low aeration conditions $(\leq 1 \mathrm{mmol}$ $\mathrm{O}_{2} / 1$.h); however, excessive aeration supply $\left(5 \mathrm{mmol} \mathrm{O}_{2} / \mathrm{l}\right.$.h) was also not suitable for the process, causing a reduction in the ethanol production. Therefore, the establishment of a suitable aeration level is of great importance to achieve high xylose conversion to ethanol.

Due to the above reasons, the present study aimed to evaluate the influence of initial xylose concentration, agitation and aeration on ethanol production by P. stipitis NRRL Y-7124, from rice straw hemicellulosic hydrolysate. Although several works on ethanol production by $P$. stipitis have been published, the research reported in this study deals with the ethanol production from rice straw hemicellulosic hydrolysate, which consists in an attractive source of sugars and nutrients for fermentative processes [16] and has been few explored for ethanol production by P. stipitis. The best experimental condition to perform this bioconversion process was established by using statistical tools. 


\section{Materials and Methods}

\section{Hydrolysate Preparation}

To be used in the experiments, rice straw was initially dried in the sun until approximately $10 \%$ moisture content, milled to attain particles of about $1 \mathrm{~cm}$ in length and $1 \mathrm{~mm}$ in thickness, and stored in bags. For the hydrolysis reaction, rice straw was impregnated with sulfuric acid solution (100 $\mathrm{mg} \mathrm{H}_{2} \mathrm{SO}_{4} / \mathrm{g}$ dry matter) in a 1:10 dry matter/acid solution ratio [17]. The acid hydrolysis was carried out in a 350-L stainless steel reactor, at $120{ }^{\circ} \mathrm{C}$, $50 \mathrm{rpm}$, during $30 \mathrm{~min}$. After hydrolysis, the residual solid material was separated by centrifugation and the liquid phase (hemicellulosic hydrolysate) was submitted to a detoxification procedure, which was performed in the same reactor used for hydrolysis. Such procedure was carried out at $45{ }^{\circ} \mathrm{C}, 50 \mathrm{rpm}$, for $30 \mathrm{~min}$, using $3 \%(w / w)$ activated charcoal, as previously established [18]. The detoxified hemicellulosic hydrolysate was separated from the solid residue material by centrifugation and submitted to a vacuum concentration process at $65{ }^{\circ} \mathrm{C}$, in a 30 -L stainless steel evaporator, aiming to increase the sugars content in sixfold. Before use as fermentation medium, the hydrolysate was diluted to the desired initial xylose concentration, and had its $\mathrm{pH}$ adjusted to 5.5 by addition of $\mathrm{NaOH}$ (pellets), the remaining solid residue being removed by centrifugation at $1,000 \times \mathrm{g}$ for $15 \mathrm{~min}$.

\section{Inoculum and Fermentation Conditions}

P. stipitis NRRL Y-7124 was the microorganism used in the experiments. Cultures of this yeast were maintained on malt extract agar slants at $4{ }^{\circ} \mathrm{C}$. For inoculum preparation, cells of the yeast in the maintenance medium were transferred to 125 -ml Erlenmeyer flasks containing $25 \mathrm{ml}$ of the medium composed by (grams per liter) xylose (30.0), urea (2.3), $\mathrm{MgSO}_{4} \times 7 \mathrm{H}_{2} \mathrm{O}$ (1.0), and yeast extract (3.0). The inoculated flasks were incubated at $30{ }^{\circ} \mathrm{C}, 200 \mathrm{rpm}$, during $24 \mathrm{~h}$. After this time, the cells were recovered by centrifugation $(1,100 \times \mathrm{g}, 20 \mathrm{~min})$ and resuspended in the fermentation medium to obtain an initial concentration of $1 \mathrm{~g} / \mathrm{l}$.

Fermentation assays for evaluation of the initial xylose concentration on ethanol production were performed in $125-\mathrm{ml}$ Erlenmeyer flasks containing $50 \mathrm{ml}$ of fermentation medium (hydrolysate diluted to different initial xylose concentrations (Table 1), not supplemented with nutrients), inoculated with $1 \mathrm{~g} / 1$ cells. The flasks were incubated in rotary shaker at $30{ }^{\circ} \mathrm{C}, 150 \mathrm{rpm}$, for $48 \mathrm{~h}$.

Table 1 Ethanol and cell concentrations and fermentative parameter values obtained during the ethanol production by Pichia stipitis from detoxified rice straw hemicellulosic hydrolysate containing different initial xylose concentrations.

\begin{tabular}{cccccc}
\hline$S_{0}(\mathrm{~g} / \mathrm{l})$ & $X_{\mathrm{f}}(\mathrm{g} / \mathrm{l})$ & $P_{\mathrm{f}}(\mathrm{g} / \mathrm{l})$ & $Y_{\mathrm{P} / \mathrm{S}}(\mathrm{g} / \mathrm{g})$ & $Y_{\mathrm{X} / \mathrm{s}}(\mathrm{g} / \mathrm{g})$ & $Q_{\mathrm{P}}(\mathrm{g} / \mathrm{l} . \mathrm{h})$ \\
\hline 88.0 & 1.74 & 0 & 0 & 0 & 0 \\
66.0 & 1.61 & 0 & 0 & 0 & 0 \\
47.0 & 2.99 & 16.00 & 0.47 & 0.05 & 0.34 \\
32.0 & 3.60 & 14.00 & 0.38 & 0.06 & 0.29 \\
\hline
\end{tabular}

$S_{0}$ initial xylose concentration, $X_{f}$ final cells concentration, $P_{f}$ final ethanol concentration, $Y_{\mathrm{P} / \mathrm{S}}$ ethanol yield factor, $Y_{X / S}$ cell yield factor, $Q_{P}$ ethanol volumetric productivity 
Fermentation assays for evaluation of aeration and agitation conditions on ethanol production were performed in 250-ml Erlenmeyer flasks containing 50, 75, or $100 \mathrm{ml}$ of fermentation medium (hydrolysate supplemented with $3 \mathrm{~g} / 1$ yeast extract), inoculated with $1 \mathrm{~g} / 1$ cells. The flasks were incubated in rotary shaker at $30{ }^{\circ} \mathrm{C}$ for $120 \mathrm{~h}$. The agitation and aeration conditions used in each experiment are shown in Table 2. During the experiments, samples were taken each $24 \mathrm{~h}$ for sugars, ethanol, and cellular growth determinations.

\section{Analyses}

Glucose, xylose, arabinose, acetic acid, and ethanol concentrations were determined by high-performance liquid chromatography (HPLC) in Waters chromatograph equipped with a refractive index detector and a Bio-Rad Aminex HPX-87H column $(300 \times$ $7.8 \mathrm{~mm}$ ). Operation conditions included temperature of $45{ }^{\circ} \mathrm{C}, 0.005 \mathrm{M}$ sulfuric acid as eluent in a flow of $0.6 \mathrm{ml} / \mathrm{min}$, and sample volume of $20 \mu 1$. The cellular growth was determined by measuring the fermentation broth UV-spectrophotometric absorbance at $600 \mathrm{~nm}$, which was correlated to a calibration curve (dry weight $\times$ optical density).

Furfural, hydroxymethylfurfural (HMF), vanillic acid, vanillin, syringaldehyde, and ferulic acid were also determined by HPLC, but using a UV detector (at $276 \mathrm{~nm}$ ) and a Waters Resolve C18 $5 \mu \mathrm{m}(3.9 \times 300 \mathrm{~mm})$ column at room temperature, acetonitrile/water ( $1 / 8$ with $10 \mathrm{~g} / 1$ acetic acid, and with the $\mathrm{pH}$ adjusted to 2.5 by addition of $\mathrm{H}_{3} \mathrm{PO}_{4}$ ) as the eluent, a flow rate of $0.8 \mathrm{ml} / \mathrm{min}$ and sample volume of $20 \mu 1$.

Ethanol yield factor $\left(Y_{\mathrm{P} / \mathrm{S}}\right.$, grams per gram) was defined as the ratio between ethanol concentration (grams per liter) and xylose consumed (grams per liter). Ethanol volumetric productivity ( $Q_{\mathrm{P}}$, grams per liter per hour) was calculated as the ratio between the ethanol concentration (grams per liter) and the fermentation time (hour). Cell yield factor $\left(Y_{\mathrm{X} / \mathrm{S}}\right.$, grams per gram) was defined as the ratio between cell concentration and total substrate consumed (grams per liter).

Table 2 Experimental matrix for ethanol yield factor $\left(Y_{\mathrm{P} / \mathrm{S}}\right)$, cell yield factor $\left(Y_{\mathrm{X} / \mathrm{S}}\right)$, and ethanol volumetric productivity $\left(Q_{\mathrm{P}}\right)$ with coded and real variable values, according to a $2^{2}$ full-factorial design with three replicates in the center point.

\begin{tabular}{|c|c|c|c|c|c|c|c|}
\hline \multirow[t]{3}{*}{ Assay } & \multicolumn{4}{|l|}{ Variables } & \multicolumn{3}{|c|}{ Responses } \\
\hline & \multicolumn{2}{|c|}{ Coded values } & \multicolumn{2}{|c|}{ Real values } & \multirow[b]{2}{*}{$Y_{\mathrm{P} / \mathrm{S}}(\mathrm{g} / \mathrm{g})$} & \multirow[b]{2}{*}{$Y_{\mathrm{X} / \mathrm{S}}(\mathrm{g} / \mathrm{g})$} & \multirow[b]{2}{*}{$Q_{\mathrm{P}}(\mathrm{g} / \mathrm{l} . \mathrm{h})$} \\
\hline & Aeration & Agitation & Aeration $^{\mathrm{a}}$ & Agitation (rpm) & & & \\
\hline 1 & -1 & -1 & 2.5 & 100 & 0.43 & 0.09 & 0.20 \\
\hline 2 & 1 & -1 & 5.0 & 100 & 0.29 & 0.11 & 0.28 \\
\hline 3 & -1 & 1 & 2.5 & 200 & 0.37 & 0.12 & 0.39 \\
\hline 4 & 1 & 1 & 5.0 & 200 & 0.22 & 0.18 & 0.29 \\
\hline 5 & 0 & 0 & 3.75 & 150 & 0.32 & 0.12 & 0.30 \\
\hline 6 & 0 & 0 & 3.75 & 150 & 0.28 & 0.13 & 0.28 \\
\hline 7 & 0 & 0 & 3.75 & 150 & 0.31 & 0.11 & 0.29 \\
\hline
\end{tabular}

\footnotetext{
a The ratio between the volume of the Erlenmeyer flask and the volume of fermentation medium used in the experiments
} 
Statistical Data Analysis

Fermentation assays were performed according to a $2^{2}$ full-factorial design with three replicates in the center point (Table 2), to evaluate the influence of agitation and aeration variables on xylose bioconversion to ethanol by $P$. stipitis from rice straw hemicellulosic hydrolysate. The ethanol yield factor $\left(Y_{\mathrm{P} / \mathrm{S}}\right)$, ethanol productivity $\left(Q_{\mathrm{P}}\right)$, and cell yield factor $\left(Y_{\mathrm{X} / \mathrm{S}}\right)$ were taken as responses of the experimental design. Statistical analysis of the data was carried out using the Statgrafics 6.0, Design-Expert 5.0, and Statistica 6.0, softwares.

\section{Results and Discussion}

\section{Hydrolysate Composition}

The main components and their concentrations in the original, detoxified, concentrated, and fermented rice straw hemicellulosic hydrolysate are shown in Table 3. It can be seen that the acid hydrolysis process promoted a selective removal of the hemicellulosic fraction, since xylose was the main obtained sugar. Detoxification process did not affect the sugars content but promoted complete removal of vanillic acid, vanillin, syringaldehyde, and ferulic acid, and elevated removal of HMF and furfural, which had their concentrations reduced in $92 \%$ and $74 \%$, respectively. In fact, detoxification with activated charcoal has been reported as efficient for toxic compounds removal from rice straw hemicellulosic hydrolysate [18]. The total removal of vanillin and syringaldehyde is particularly of great relevance since both compounds were identified as being of high toxicity for P. stipitis [10].

When submitted to a concentration process, the hydrolysate had sugars concentration increase proportional to the used concentration factor (sixfold), while the acetic acid content was reduced in $75 \%$. HMF and furfural concentrations were increased, but not proportionally to the used concentration factor. Even so, the toxic compounds (acetic acid,

Table 3 Concentration of sugars and main toxic compounds in rice straw hemicellulosic hydrolysate in the forms: original $(\mathrm{OH})$, detoxified with activated charcoal $(\mathrm{DH})$, concentrated $(\mathrm{CDH})$, and used as fermentation medium $(\mathrm{FH})$.

\begin{tabular}{lclll}
\hline Component & OH & DH & CDH & FH \\
\hline Sugars & & & & \\
$\quad$ Glucose $(\mathrm{g} / \mathrm{l})$ & 3.1 & 3.0 & 18.7 & 7.5 \\
Xylose $(\mathrm{g} / \mathrm{l})$ & 19.0 & 18.2 & 114.9 & 49.5 \\
$\quad$ Arabinose (g/l) & 3.1 & 2.9 & 17.1 & 8.5 \\
Toxic compounds & & & & \\
Acetic acid (g/l) & 1.5 & 1.2 & 0.3 & n.d \\
Hydroxymethylfurfural (mg/l) & 54 & 4 & 7 & 3 \\
Furfural (mg/l) & 132 & 34 & 103 & 7.7 \\
Vanillic acid (mg/l) & 71 & n.d. & n.d. & n.d \\
Vanillin (mg/l) & 45 & n.d. & n.d. & n.d \\
Syringaldehyde (mg/l) & 288 & n.d. & n.d. & n.d \\
Ferulic acid (mg/l) & 67 & n.d. & n.d. & n.d \\
\hline
\end{tabular}

n.d. not detected 
HMF, and furfural) were present in the concentrated hydrolysate in levels below to those reported to cause inhibition of the microbial metabolism. For example, ethanol production by P. stipitis CECT 1922 was not affected by furfural concentrations up to $2 \mathrm{~g} / \mathrm{l}$, neither by acetic acid concentrations up to $6 \mathrm{~g} / \mathrm{l}$. The simultaneous presence of acetic acid $(1.5 \mathrm{~g} / \mathrm{l})$, formic acid $(0.5 \mathrm{~g} / 1)$, and furfural $(1 \mathrm{~g} / 1)$ did not affect also the microorganism performance in converting xylose and glucose to ethanol [19]. According to the authors, such compounds when not present in concentration high enough to totally inhibit cellular growth exert a positive effect on ethanol yields. Cantarella et al. [20] reported also that ethanol yields were increased during the fermentation of poplar wood hydrolysates in the presence of acetic acid, vanillin and HMF. Recently, it was demonstrated that $P$. stipitis reduces the aldehydes group in the furan ring of HMF and furfural [21, 22], and is able to consume acetic acid during fermentation [23].

\section{Effect of Initial Xylose Concentration on Ethanol Production}

Establishing the initial substrate concentration to be used in a fermentation process is important to attain elevated product formation. Therefore, the present work evaluated, in a first stage, the effect of different initial xylose concentrations on ethanol production by $P$. stipitis from rice straw hemicellulosic hydrolysate. By dilution of the detoxified hydrolysate, xylose concentrations varying from 32 to $88 \mathrm{~g} / 1$ were obtained. The initial and final concentrations of xylose, cells and ethanol, as well as the fermentative parameters values (ethanol $\left(Y_{\mathrm{P} / \mathrm{S}}\right)$ and cell $\left(Y_{\mathrm{X} / \mathrm{S}}\right)$ yields, and the ethanol productivity $\left.\left(Q_{\mathrm{P}}\right)\right)$ obtained in each one of these experiments are shown in Table 1.

According to the results, sugars consumption, cell growth, and ethanol production only occurred for initial xylose concentrations of 47 and $32 \mathrm{~g} / \mathrm{l}$. For xylose concentrations higher than $47 \mathrm{~g} / \mathrm{l}$, any product formation was not observed, although the microorganism was able to grow in these media. This means that under these conditions, the metabolism of the yeast P. stipitis was inhibited, even using the previously detoxified hydrolysate, i.e., with a large amount of the toxic compounds removed during the activated charcoal treatment. To overcome the inhibition problem thus found, the subsequent study on ethanol production by P. stipitis was performed using rice straw hemicellulosic hydrolysate containing an initial xylose concentration of about $50 \mathrm{~g} / \mathrm{l}$. du Preez et al. [24] reported also that initial xylose concentration had a significant effect on the fermentation parameters of $P$. stipitis with maximum ethanol productivities occurring at xylose concentration of $50 \mathrm{~g} / \mathrm{l}$.

\section{Effect of Agitation and Aeration on Ethanol Production}

P. stipitis was able to produce ethanol in all the evaluated fermentation conditions; however, the maximum product concentration varied according to the agitation and aeration level employed. Table 2 shows the ethanol $\left(Y_{\mathrm{P} / \mathrm{S}}\right)$ and cell $\left(Y_{\mathrm{X} / \mathrm{S}}\right)$ yields, and the ethanol productivity $\left(Q_{\mathrm{P}}\right)$ obtained in each experimental condition. Statistical analysis of these data revealed that the aeration (factor A) had a main effect significant at $95 \%$ confidence level for the responses $Y_{\mathrm{P} / \mathrm{S}}$ and $Y_{\mathrm{X} / \mathrm{S}}$. However, such effect had a negative signal for $Y_{\mathrm{P} / \mathrm{S}}$ and positive signal for $Y_{\mathrm{X} / \mathrm{S}}$, suggesting that the lowest aeration level favored the ethanol production, while the highest level favored the cell growth (Table 4). The agitation (factor B) level had also influence on $Y_{\mathrm{P} / \mathrm{S}}$ and $Y_{\mathrm{X} / \mathrm{S}}$ responses, with a positive signal significant at $95 \%$ confidence level for $Y_{\mathrm{X} / \mathrm{S}}$ and a negative signal significant at $90 \%$ confidence level for $Y_{\mathrm{P} / \mathrm{S}}$. For ethanol productivity $\left(Q_{\mathrm{P}}\right)$, the agitation was the unique main variable with statistically significant effect. Nevertheless, although the aeration effect was not statistically 
Table 4 Effect estimates (EE), standard errors (SE), and $t$ test results for ethanol yield factor $\left(Y_{\mathrm{P} / \mathrm{S}}\right)$, cell yield factor $\left(Y_{\mathrm{X} / \mathrm{S}}\right)$, and ethanol volumetric productivity $\left(Q_{\mathrm{P}}\right)$ during the xylose-to-ethanol conversion by Pichia stipitis from rice straw hemicellulosic hydrolysate, according to a $2^{2}$ full-factorial design with three replicates in the center point.

\begin{tabular}{|c|c|c|c|c|c|c|c|c|c|}
\hline \multirow{2}{*}{$\begin{array}{l}\text { Variables and } \\
\text { interactions }\end{array}$} & \multicolumn{3}{|l|}{$Y_{\mathrm{P} / \mathrm{S}}$} & \multicolumn{3}{|l|}{$Y_{\mathrm{X} / \mathrm{S}}$} & \multicolumn{3}{|l|}{$Q_{\mathrm{P}}$} \\
\hline & $\mathrm{EE}$ & SE & $t$ test & $\mathrm{EE}$ & $\mathrm{SE}$ & $t$ test & $\mathrm{EE}$ & $\mathrm{SE}$ & $t$ test \\
\hline Aeration & -0.1450 & \pm 0.0250 & $-5.8111^{\mathrm{b}}$ & 0.0400 & \pm 0.0090 & $4.4458^{\mathrm{b}}$ & -0.0100 & \pm 0.0082 & -1.2247 \\
\hline Agitation & -0.0650 & \pm 0.0250 & $-2.6050^{\mathrm{c}}$ & 0.0500 & \pm 0.0090 & $5.5572^{\mathrm{b}}$ & 0.1000 & \pm 0.0082 & $12.2474^{\mathrm{a}}$ \\
\hline $\begin{array}{c}\text { Aeration } \times \\
\text { agitation }\end{array}$ & -0.0050 & \pm 0.0250 & -0.2004 & 0.0200 & \pm 0.0090 & 2.2229 & -0.0900 & \pm 0.0082 & $-11.0227^{\mathrm{a}}$ \\
\hline
\end{tabular}

${ }^{\mathrm{a}} p<0.01{ }^{\mathrm{b}} p<0.05 ;{ }^{\mathrm{c}} p<0.10$;

significant for this response even at $90 \%$ confidence level, its interaction with the agitation was significant at $99 \%$ confidence level for $Q_{\mathrm{P}}$, with a negative signal, which suggests that the highest $Q_{\mathrm{P}}$ values can be achieved when the lowest aeration levels are used.

Based on the statistical analysis results, mathematical models describing the responses $Y_{\mathrm{P} / \mathrm{S}}, Y_{\mathrm{X} / \mathrm{S}}$, and $Q_{\mathrm{P}}$ within the studied region were established (Eqs. 1, 2, and 3, respectively). All the models presented determination coefficients $\left(R^{2}\right)$ higher than 0.90 , explaining thus more than $90 \%$ of the responses variations.

$$
\begin{array}{cc}
Y_{\mathrm{P} / \mathrm{S}}=0.317-0.073 \mathrm{~A}-0.033 \mathrm{~B} & \left(R^{2}=0.93\right) \\
Y_{\mathrm{X} / \mathrm{S}}=0.123+0.020 \mathrm{~A}+0.025 \mathrm{~B} & \left(R^{2}=0.95\right) \\
Q_{\mathrm{P}}=0.290-0.010 \mathrm{~A}+0.100 \mathrm{~B}-0.090 \mathrm{AB} & \left(R^{2}=0.99\right)
\end{array}
$$

Through the Eqs. 1, 2, and 3, it was possible to plot response surfaces describing the variations in the responses $Y_{\mathrm{P} / \mathrm{S}}, Y_{\mathrm{X} / \mathrm{S}}$, and $Q_{\mathrm{P}}$, within the studied region (Fig. 1a, b, and c, respectively). Figure 1a shows that the increase in the value of both variables had a negative influence on ethanol yield, the aeration effect being more evident than the agitation effect. The maximum $Y_{\mathrm{P} / \mathrm{S}}$ value (about $0.42 \mathrm{~g} / \mathrm{g}$ ), was obtained when the lowest agitation $(100 \mathrm{rpm})$ and aeration ( $2.5 V_{\text {flask }} / V_{\text {medium }}$ ratio) levels were used.

Unlike $Y_{\mathrm{P} / \mathrm{S}}$, the increase in the variables values had a positive influence on $Y_{\mathrm{X} / \mathrm{S}}$, as can be seen in Fig. 1b. The maximum $Y_{\mathrm{X} / \mathrm{S}}$ value (about $0.16 \mathrm{~g} / \mathrm{g}$ ), was obtained when the highest agitation $(200 \mathrm{rpm})$ and aeration $\left(5.0 V_{\text {flask }} / V_{\text {medium }}\right.$ ratio $)$ levels were used. The $Y_{\mathrm{P} / \mathrm{S}}$ and $Y_{\mathrm{X} / \mathrm{S}}$ results shows that the carbon flow division between cell growth and product formation is strongly influenced by the aeration level used during the fermentation. Increasing the agitation from 100 to $150 \mathrm{rpm}$ promoted also a higher cell growth rate during the ethanol production by $P$. stipitis CBS 6054 from corn stover hemicellulose hydrolysate [23]. Biomass concentration increase was also verified when the agitation was increased (from 70 to $130 \mathrm{rpm}$ ) during fermentation of sunflower seed hull hydrolysate to ethanol by P. stipitis NRRL Y-7124 [25]. According to Skoog and Hahn-Hägerdal [26], oxygen plays an important role in cell growth, redox balance, functioning of the mitochondria, and generation of energy for xylose transport in $P$. stipitis. Since this yeast is respirefermentative [27], excess oxygenation could lead to low ethanol yields. Some studies have 

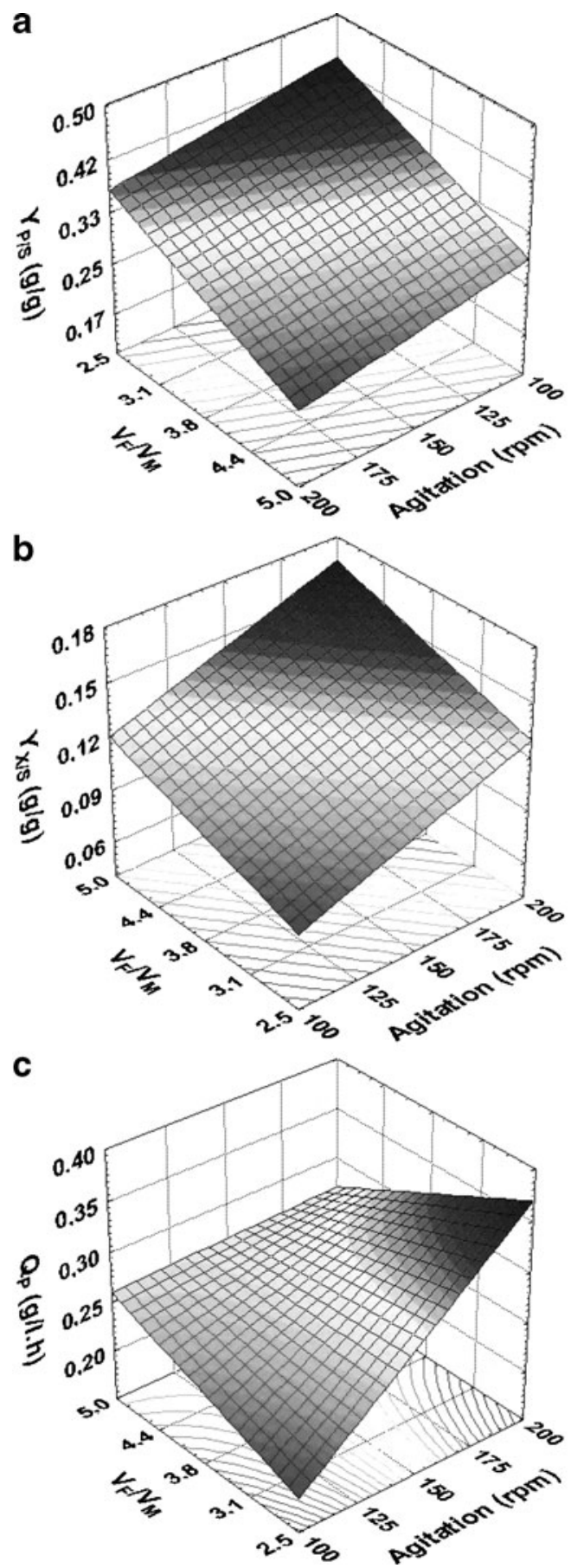

Fig. 1 Response surfaces for ethanol yield factor (a), cell yield factor (b) and ethanol volumetric productivity (c) as a function of the agitation and aeration ( $V_{\text {flask }} / V_{\text {medium }}$ ratio) used during the rice straw hemicellulosic hydrolysate fermentation by Pichia stipitis 
shown that $P$. stipitis produces ethanol under anaerobic conditions, but microaerobic conditions appear to be optimal for ethanol production [10].

Figure 1c shows the $Q_{\mathrm{P}}$ variations as a function of the aeration and agitation levels. It can be noted in this figure that the agitation increase had a strong positive influence in the $Q_{\mathrm{P}}$ values when the aeration was set at the lowest level. On the other hand, when the aeration was set at the highest level, changes in the agitation showed no significant effect in the productivity. Curiously, the aeration had opposite effects in the $Q_{\mathrm{P}}$ values when used in the lowest or in the highest agitation levels. A positive effect of the aeration increase in $Q_{\mathrm{P}}$ was observed under the lowest agitation level; whereas a negative effect of the aeration increase was noted under the highest agitation level. Maximum $Q_{\mathrm{P}}$ value (about $0.39 \mathrm{~g} / \mathrm{l}$.h) was obtained when using the highest agitation $(200 \mathrm{rpm})$ and the lowest aeration level ( $2.5 V_{\text {flask }} / V_{\text {medium }}$ ratio). Other authors have also shown that the volumetric productivity rates increases with increased agitation [25].

Based on the discussion above, the fermentation condition able to promote high $Y_{\mathrm{P} / \mathrm{S}}$ and $Q_{\mathrm{P}}$ values was established. Such condition consisted in using $200 \mathrm{rpm}$ agitation (maximum evaluated value) and $2.5 V_{\text {flask }} / V_{\text {medium }}$ ratio (minimum evaluated value). Although low aeration and agitation levels lead to the highest $Y_{\mathrm{P} / \mathrm{S}}$ values, under these conditions the xylose consumption was very slow, which affected the $Q_{\mathrm{P}}$ values. High aeration levels caused faster substrate consumption, but the xylose conversion under these conditions was low, due to the product oxidation or the high growing cell. By using these established fermentation conditions the xylose conversion yield to ethanol $\left(Y_{\mathrm{P} / \mathrm{S}}\right)$ and the ethanol volumetric productivity $\left(Q_{\mathrm{P}}\right)$ were $0.37 \mathrm{~g} / \mathrm{g}$ and $0.39 \mathrm{~g} / \mathrm{l} . \mathrm{h}$, respectively. Such value corresponded to a process efficiency of $72.5 \%$, since in the absence of cell growth and maintenance, the maximum theoretical yield of ethanol from xylose in yeasts has been considered to be $0.51 \mathrm{~g}$ ethanol/g xylose consumed [7, 28].

The ethanol yield and productivity obtained in the present work $(0.37 \mathrm{~g} / \mathrm{g}$ xylose $)$ can be well compared to others achieved using hemicellulosic hydrolysates from different lignocellulosic wastes. For example, hemicellulosic hydrolysate produced from dilute acid pretreatment of corn stover was fermented to ethanol by P. stipitis CBS 6054 with yields between $0.37-0.44 \mathrm{~g} / \mathrm{g}$ (glucose + xylose), but productivity of only $0.21 \mathrm{~g} / \mathrm{l} . \mathrm{h}$ [23]. Ethanol yield and productivity were $0.32 \mathrm{~g} / \mathrm{g}$ and $0.065 \mathrm{~g} / \mathrm{l} . \mathrm{h}$ during fermentation of sunflower seed hull hydrolysate to ethanol by P. stipitis NRRL Y-7124 [25]. Much better results were attained using this same yeast in rice straw hemicellulosic hydrolysate (present work), suggesting that our substrate has great potential for use on ethanol production.

\section{Conclusions}

P. stipitis NRRL Y-7124 was able to produce ethanol from rice straw hemicellulosic hydrolysate, but the initial xylose concentration, as well as the aeration and agitation conditions, was found as important variables affecting the efficiency of this process. Initial xylose concentration of $50 \mathrm{~g} / \mathrm{l}$ was the most suitable for the process development; and $200 \mathrm{rpm}$ agitation and $2.5\left(V_{\text {flask }} / V_{\text {medium }}\right.$ ratio) aeration was the best operational condition in the studied range of values, able to promote high $Y_{\mathrm{P} / \mathrm{S}}(0.37 \mathrm{~g} / \mathrm{g})$ and $Q_{\mathrm{P}}(0.39 \mathrm{~g} / \mathrm{l} . \mathrm{h})$ values. Under this condition, a process efficiency of $72.5 \%$ was achieved. These results demonstrated that the establishment of adequate conditions of aeration is of great relevance to improve the ethanol production from xylose by $P$. stipitis, using rice straw hemicellulosic hydrolysate as fermentation medium. 
Acknowledgements The financial support from Fapesp (Brazil) is gratefully acknowledged.

\section{References}

1. Hu, G., Heitmann, J. A., \& Rojas, O. J. (2008). Bioresources, 3, 270-294.

2. Kumar, A., Singh, L. K., \& Ghosh, S. (2009). Bioresource Technology, 100, 3293-3297. doi:10.1016/j. biortech.2009.02.023.

3. Demirbas, A. (2005). Energy Sources, 27, 327-337. doi:10.1080/00908310390266643.

4. Zaldivar, J., Nielsen, J., \& Olsson, L. (2001). Applied Microbiology and Biotechnology, 56, 17-34. doi:10.1007/s002530100624.

5. Duff, S. J. B., \& Murray, W. D. (1996). Bioresource Technology, 55, 1-33. doi:10.1016/0960-8524(95) 00122-0.

6. Mussatto, S. I., \& Roberto, I. C. (2004). Bioresource Technology, 93, 1-10. doi:10.1016/j. biortech.2003.10.005.

7. Hahn-Hägèrdal, B., Jeppsson, H., Skoog, K., \& Prior, B. A. (1994). Enzyme and Microbial Technology, 16, 933-943. doi:10.1016/0141-0229(94)90002-7.

8. Millati, R., Edebo, L., \& Taherzadeh, M. J. (2004). Enzyme and Microbial Technology, 36, 294-300. doi:10.1016/j.enzmictec.2004.09.007.

9. Sanchez, G., Pilcher, L., Roslander, C., Modig, T., Galbe, M., \& Linden, G. (2004). Bioresource Technology, 93, 249-256. doi:10.1016/j.biortech.2003.11.003.

10. Agbogbo, F. K., \& Coward-Kelly, G. (2008). Biotechnology Letters, 30, 1515-1524. doi:10.1007/ s10529-008-9728-z.

11. Sánchez, S., Bravo, V., Castro, E., Moya, A. J., \& Camacho, F. (2002). Journal of Chemical Technology and Biotechnology, 77, 641-648. doi:10.1002/jctb.622.

12. Sunitha, K., Lee, J. K., \& Oh, T. K. (1999). Bioprocess and Biosystems Engineering, 21, 477-481. doi:10.1007/PL00009086.

13. du Preez, J. C. (1994). Enzyme and Microbial Technology, 16, 944-956. doi:10.1016/0141-0229(94) 90003-5.

14. Taniguchi, M., Tohma, T., Itaya, T., \& Fujii, M. (1997). Journal of Fermentation and Bioengineering, 83, 364-370. doi:10.1016/S0922-338X(97)80143-2.

15. Nigam, J. N. (2001). Journal of Industrial Microbiology and Biotechnology, 26, 145-150. doi:10.1038/ s.j.jim. 7000098 .

16. Mussatto, S. I., \& Roberto, I. C. (2005). Brazilian Archives of Biology and Technology, 48, 497-502. doi:10.1590/S1516-89132005000300020.

17. Roberto, I. C., Mussatto, S. I., \& Rodrigues, R. C. L. B. (2003). Industrial Crops and Products, 17, 171176. doi:10.1016/S0926-6690(02)00095-X.

18. Mussatto, S. I., \& Roberto, I. C. (2004). Biotechnology Progress, 20, 134-139. doi:10.1021/bp034207i.

19. Diaz, M. J., Ruiz, E., Romero, I., Cara, C., Moya, M., \& Castro, E. (2009). World Journal of Microbiology and Biotechnology, 25, 891-899. doi:10.1007/s11274-009-9966-9.

20. Cantarella, M., Cantarella, L., Gallifuoco, A., Spera, A., \& Alfani, F. (2004). Biotechnology Progress, 20, 200-206. doi:10.1021/bp0257978.

21. Liu, Z. L., Slininger, P. J., Dien, B. S., Berhow, M. A., Kurtzman, C. P., \& Gorsick, S. W. (2004). Journal of Industrial Microbiology and Biotechnology, 31, 345-352. doi:10.1007/s10295-004-0148-3.

22. Liu, Z. L., Slininger, P. J., \& Gorsick, S. W. (2005). Applied Biochemistry and Biotechnology, 121-124, 451-460. doi:10.1007/978-1-59259-991-2.

23. Agbogbo, F. K., \& Wenger, K. S. (2007). Journal of Industrial Microbiology and Biotechnology, 34, 723-727. doi:10.1007/s10295-007-0247-z.

24. du Preez, J. C., Bosch, M., \& Prior, B. A. (1986). Enzyme and Microbial Technology, 8, 360-364. doi:10.1016/0141-0229(86)90136-5.

25. Telli-Okur, M., \& Eken-Saraçoglu, N. (2008). Bioresource Technology, 99, 2162-2169. doi:10.1016/j. biortech.2007.05.036.

26. Skoog, K., \& Hahn-Hagerdahl, B. (1990). Applied and Environmental Microbiology, 56, 3389-3394.

27. Klinner, U., Fluthgraf, S., Freese, S., \& Passoth, V. (2005). Applied Microbiology and Biotechnology, 67, 247-253. doi:10.1007/s00253-004-1746-8.

28. Slininger, P. J., Bothast, R. J., Okos, M. R., \& Ladisch, M. R. (1985). Biotechnology Letters, 7, 431-436. doi:10.1007/BF01166218. 